\title{
Anthropometric Profiles and Somatotypes of Female Volleyball and Beach Volleyball Players
}

\author{
Perfiles Antropométricos y Somatotipos de Jugadoras de Voleibol Femenino y Voleibol de Playa
}

\author{
Ruggero D’Anastasio ${ }^{1,2}$; Andrea Milivojevic ${ }^{3}$; Jacopo Cilli'; ${ }^{4}$ Iuri Icaro ${ }^{3}$ \& Joan Viciano ${ }^{1}$
}

D’ANAStaSiO, R.; MILIVOJEVIC, A.; CILLI, J.; ICARO, I. \& VICIANO, J. Anthropometric profiles and somatotypes of female volleyball and beach volleyball players. Int. J. Morphol., 37(4):1480-1485, 2019.

SUMMARY: The aim was to compare anthropometric profiles, body composition, and somatotypes of female volleyball players grouped according to player status (National League Divisions) and function. The study assessed 62 volleyball players and 12 beach volleyball players (mean age, 23.58, s = 7.74 years). Anthropometric measures included height, body mass, body circumferences and diameters, adipose skinfold thickness. Data processing using a dietetic software package provided body mass index, fat mass percentage, arm muscular area, thigh muscular area, and somatotype. Statistical analysis was performed using SPSS Statistics version 22. Division B volleyball players were taller than those in Division C $(169.19, \mathrm{~s}=6.68 \mathrm{~cm}$ vs. $165.40, \mathrm{~s}=6.19 \mathrm{~cm} ; \mathrm{P}<0.05)$, but showed lower arm muscular area $(34.77, \mathrm{~s}=3.57 \mathrm{~cm} 2$ vs. $40.06, \mathrm{~s}=7.27 \mathrm{~cm} 2 ; \mathrm{p}<0.05)$ and mesomorphy $(3.40, \mathrm{~s}=1.21$ vs. $4.84, \mathrm{~s}=2.10 ; \mathrm{P}<0.05)$. For player functions, blockers were the tallest $(172.38, \mathrm{~s}=4.18 \mathrm{~cm} ; \mathrm{P}<0.05)$ and showed the highest ectomorphy $(3.08, \mathrm{~s}=1.02 ; \mathrm{P}<0.05)$, setters showed the highest fat mass percentage $(26.38 \%, \mathrm{~s}=2.99 \%: \mathrm{P}<0.05)$, and 'liberos' showed a more compact mesomorphy $(5.46, \mathrm{~s}=2.13)$ and low ectomorphy $(1.58, \mathrm{~s}=0.90)$. The anthropometric data showed few significant differences between the volleyball Divisions, suggesting that promotion up the Divisions is due to technical ability rather than physical qualities. The anthropometric profiles of the players varied according to their functions within their volleyball team.

KEY WORDS: Body composition; Team sport; Measurement.

\section{INTRODUCTION}

Volleyball is a team sport that alternates between high athletic intensity and relatively less strenuous moments during the play (González-Ravé et al., 2011). When playing, the players perform different movements (e.g., jump, dive, roll, rapid forward and lateral movements) that require strength, power, agility and speed (Lidor \& Ziv, 2010). Gonzales-Rave and colleagues demonstrated that body composition has a crucial role in determining athletic performance in volleyball players (González-Ravé et al.).

A volleyball team has 12 players, of which 6 will be playing at any one time. These players have different functions while the game is in play (Gabbett \& Georgieff, 2007), which can generally be classified as: hitters (outside and opposite), setters, blockers and 'liberos'. The differentiation of each function requires definition of the anthropomorphic and physiological profiles relevant to each, to adequately respond to the necessary performance and tactical demands (Sheppard et al., 2009a,b).
The anthropometric profile and the somatotype characterisation of top volleyball players can provide useful information on not only the physical conditions of the athletes, but also on their potential performance in relation to the function that they have during the volleyball game (Gualdi-Russo \& Zaccagni, 2001). Statistical anthropometric data are available for top volleyball players of various nationalities and ages (Gualdi-Russo \& Zaccagni; Duncan et al., 2006; Carvajal et al., 2012). However, there are fewer data available relative to volleyball players from the lower Divisions (Nikolaidis et al., 2012; Nikolaidis, 2013) and to the best of our knowledge, there are no data relative to such non-professional Italian athletes in the literature.

The goal of the present study was to compare the anthropometric characteristics, body composition, and somatotypes across non-professional female Italian volleyball players in relation to the different Divisions their team plays in and the different functions that they have during the game.

\footnotetext{
${ }^{1}$ Department of Medicine and Aging Sciences, State University "G. d'Annunzio", Chieti-Pescara, Italy.

${ }^{2}$ Associazione Sportiva Dilettantistica "Filippide Montesilvano", Montesilvano (PE), Italy.

${ }^{3}$ Operative Unit of Anthropology, State University "G. d'Annunzio”, Chieti-Pescara, Italy.

${ }^{4}$ Department of Letters, Arts and Social Sciences, State University "G. d'Annunzio", Chieti-Pescara, Italy.
} 


\section{MATERIAL AND METHOD}

The sample $(\mathrm{N}=74)$ was composed of 62 volleyball players from different Divisions (Division B in the national leagues, and Divisions $\mathrm{C}$ and $\mathrm{D}$ in the regional leagues) and function (hitters: $\mathrm{n} .27$, setters: $\mathrm{n} .10$, middle blockers: $\mathrm{n} .12$, liberos: n. 10, all-rounders: n. 13). To provide further comparisons, 12 beach volleyball players were also analysed. The mean age for all 74 of these athletes was $23.58, \mathrm{~s}=7.74$ years.

Volleyball is highly specialised sport discipline where each player has determined functions according to their playing position: setters are the playmaker of the team and partecipate in every phase of the game; they are involved in

Table I. Descriptive statistics according to volleyball player status.

\begin{tabular}{|c|c|c|c|c|c|}
\hline Player status (n) & Measure & Mean & $\pm \mathrm{SD}$ & Minimum & Maximum \\
\hline \multirow[t]{9}{*}{ Division B (24) } & Height $(\mathrm{cm})$ & 169.19 & 6.68 & 154.30 & 178.60 \\
\hline & Weight (kg) & 62.94 & 7.64 & 50.90 & 78.60 \\
\hline & Fat mass $(\%)$ & 24.45 & 2.50 & 20.10 & 27.50 \\
\hline & Body mass index $\left(\mathrm{kg} / \mathrm{m}^{2}\right)$ & 21.98 & 2.37 & 19.17 & 29.50 \\
\hline & Arm muscle area $\left(\mathrm{cm}^{2}\right)$ & 34.77 & 3.57 & 27.53 & 40.42 \\
\hline & Thigh muscle area $\left(\mathrm{cm}^{2}\right)$ & 157.80 & 19.29 & 120.02 & 200.98 \\
\hline & Endomorph component & 5.33 & 0.75 & 4.00 & 6.50 \\
\hline & Mesomorph component & 3.40 & 1.22 & 1.50 & 7.00 \\
\hline & Ectomorph component & 2.73 & 0.98 & 0.50 & 4.50 \\
\hline \multirow[t]{9}{*}{ Division C (28) } & Height $(\mathrm{cm})$ & 165.40 & 6.19 & 154.00 & 176.50 \\
\hline & Weight (kg) & 62.82 & 8.24 & 43.70 & 81.20 \\
\hline & Fat mass $(\%)$ & 24.83 & 3.51 & 19.50 & 31.80 \\
\hline & Body mass index $\left(\mathrm{kg} / \mathrm{m}^{2}\right)$ & 22.98 & 2.99 & 17.03 & 30.64 \\
\hline & Arm muscle area $\left(\mathrm{cm}^{2}\right)$ & 40.06 & 7.27 & 28.60 & 58.63 \\
\hline & Thigh muscle area $\left(\mathrm{cm}^{2}\right)$ & 161.32 & 27.46 & 111.43 & 228.96 \\
\hline & Endomorph component & 5.52 & 0.96 & 3.50 & 7.00 \\
\hline & Mesomorph component & 4.84 & 2.10 & 0.50 & 10.00 \\
\hline & Ectomorph component & 2.18 & 1.20 & 0.50 & 5.00 \\
\hline \multirow[t]{9}{*}{ Division D (10) } & Height $(\mathrm{cm})$ & 166.92 & 5.28 & 157.50 & 176.60 \\
\hline & Weight (kg) & 60.69 & 8.38 & 48.90 & 73.40 \\
\hline & Fat mass $(\%)$ & 22.97 & 3.78 & 14.20 & 27.00 \\
\hline & Body mass index $\left(\mathrm{kg} / \mathrm{m}^{2}\right)$ & 21.73 & 2.35 & 17.96 & 25.34 \\
\hline & Arm muscle area $\left(\mathrm{cm}^{2}\right)$ & 36.90 & 5.18 & 28.81 & 45.56 \\
\hline & Thigh muscle area $\left(\mathrm{cm}^{2}\right)$ & 150.27 & 26.39 & 123.82 & 201.80 \\
\hline & Endomorph component & 5.15 & 1.03 & 3.00 & 6.50 \\
\hline & Mesomorph component & 3.55 & 1.14 & 2.00 & 5.00 \\
\hline & Ectomorph component & 2.65 & 1.20 & 1.00 & 4.50 \\
\hline \multirow[t]{9}{*}{ Beach volleyball } & Height $(\mathrm{cm})$ & 165.84 & 8.44 & 148.50 & 183.70 \\
\hline & Weight (kg) & 61.18 & 5.77 & 50.10 & 67.30 \\
\hline & Fat mass $(\%)$ & 23.17 & 2.79 & 17.00 & 25.60 \\
\hline & Body mass index $\left(\mathrm{kg} / \mathrm{m}^{2}\right)$ & 22.26 & 1.57 & 19.08 & 24.13 \\
\hline & Arm muscle area $\left(\mathrm{cm}^{2}\right)$ & 34.91 & 4.60 & 29.82 & 45.03 \\
\hline & Thigh muscle area $\left(\mathrm{cm}^{2}\right)$ & 159.66 & 31.73 & 126.11 & 242.83 \\
\hline & Endomorph component & 4.92 & 0.73 & 3.50 & 6.00 \\
\hline & Mesomorph component & 3.29 & 1.12 & 1.00 & 5.00 \\
\hline & Ectomorph component & 2.33 & 1.03 & 1.00 & 5.00 \\
\hline
\end{tabular}

blocking and defence too; hitters are intensely involved in spiking and blocking and, secondary, in defense; the middle blockers are the players that execute the most blocks; at the same time they are involved in hit and, less intensely, in dig actions; opposite players execute most of the spikes of its team but also have an important role blocking; sometimes they play a role in defence and reception; libero player is specialized in reception and defence; he plays in the back court and cannot serve, set inside of the 3 meter line, or spike. The anthropometric profile of a group of players with mixed functions through the course of the season was also defined, with these players classified into the category of 'all-rounders'.

The anthropometric measures (Table I) were taken following the International Society for the Advancement of Kinanthropometry (ISAK) recommendation. The thickness of the subcutaneous fat folds was measured using Harpenden skinfold callipers, with an accuracy of $0.2 \mathrm{~mm}$. The data were then processed to obtain the following parameters: body mass index (BMI), fat mass percentage (FM\%), arm muscle area (AMA), thigh muscle area (TMA), and somatotype (Brozek et al., 1963; Heat \& Carter, 1967; Jackson et al., 1980; Cagnazzo \& Cagnazzo, 2009).

Statistical data processing was performed using the SPSS Statistics V22.0 software (IBM). Initially, the normality of the data was determined using KolmogorovSmirnov tests, and the homogeneity of the variance using Levene tests. Subsequently, descriptive analysis was performed according to the volleyball Divisions (i.e., B, C, D) and the player functions.

The differences between the means for the various Divisions and player functions were analysed using non-parametric Mann-Whitney tests. Significance was set at $\mathrm{P}<0.05$. Using the intraclass correlation coefficient (ICC), the differences between the means of all of the measurements collected at three different times were also analysed, to define possible intra-observer errors. The ICCs were interpreted based on the classification proposed by Fleiss (1986). 


\section{RESULTS}

Table I shows the anthropometric and somatotype (i.e., endomorphy, mesomorphy, ectomorphy) data of the volleyball players according to the volleyball player status (i.e., Divisions B, C, D, beach volleyball). Table II gives the results of the MannWhitney $\mathrm{U}$ tests where statistically significant differences were seen between the anthropometric and somatotype measures of the volleyball players in the categories studied.

Table III gives the descriptive results of the analysis carried out on these volleyball players subdivided by their functions in the team, with the results of the Mann-Whitney $\mathrm{U}$ tests here given in Table IV.

The analysis of the data reproducibility through the intraclass correlation coefficients showed a strength of agreement as defined by Fleiss of 'very good' for all of the measures (Table V).

\section{DISCUSSION}

In professional volleyball, each position requires specific motor skills, and these are reflected in the anthropomorphic characteristics of the players. Generally, in professional tournaments (Divisions A1, A2), the liberos and setters are the shorter athletes; furthermore, the liberos are the players with lower body weight (Marques et al., 2009; Trajkovic et al., 2011; Carvajal et al.).

The volleyball players of the Italian Division B had a markedly lower height and weight than that of the compatriot elite players (Gualdi-Russo \& Zaccagni). The mean heights of Italian amateur volleyball players are lower than those of Greek amateur athletes, while their mean weight is in line with what was reported for their Greek counterparts (Nikolaidis). The Italian players have higher FM\% than the Greek amateur colleagues (Nikolaidis).

The anthropometric profile of the volleyball players who have different functions when playing in the team is related to the technical and tactical needs that are requested of them. Regarding to the professional volleyball players, the blockers are taller and get better blocks performance; conversely, the setters need to be faster and more agile, and therefore well muscled, dynamic players who are relatively short, are preferred for this function (Gualdi-Russo \& Zaccagni; Carvajal et al.). The same trend is observed in the amateur Italian volleyball players.

The mean somatotype across the full player sample examined in the present study was $5.39, \mathrm{~s}=0.89-4.07, \mathrm{~s}=$ $1.79-2.47, \mathrm{~s}=1.13$. The endomorphic component thus prevails over the other components, regardless of the Division (i.e., Divisions B, C, D) and the player function. Setters and liberos show higher mesomorphy, that is the expression of increased musculoskeletal system development.

Table II. Results of Mann-Whitney analysis (U) for evaluation of the significance (p) of the mean differences between the various levels of player status.

\begin{tabular}{llccc}
\hline Measure & Player status comparison & $\boldsymbol{n}$ & $\boldsymbol{U}$ & $\boldsymbol{p}$ \\
\hline Height $(\mathrm{cm})$ & Division B $v s$. Division C & $24 / 28$ & 221.500 & $\mathbf{0 . 0 3 6}$ \\
& Division B $v s$. Division D & $24 / 10$ & 87.500 & 0.219 \\
& Division B $v s$. Beach volleyball & $24 / 12$ & 100.500 & 0.144 \\
& Division C $v s$. Division D & $28 / 10$ & 115.000 & 0.407 \\
& Division C $v s$. Beach volleyball & $28 / 12$ & 164.000 & 0.906 \\
& Division D $v s$. Beach volleyball & $10 / 12$ & 55.000 & 0.741 \\
\hline Arm muscle area $\left(\mathrm{cm}^{2}\right)$ & Division B $v s$. Division C & $24 / 28$ & 181.500 & $\mathbf{0 . 0 0 5}$ \\
& Division B $v s$. Division D & $24 / 10$ & 91.000 & 0.273 \\
& Division B $v s$. Beach volleyball & $24 / 12$ & 131.500 & 0.675 \\
& Division C $v s$. Division D & $28 / 10$ & 111.000 & 0.336 \\
& Division C $v s$. Beach volleyball & $28 / 12$ & 94.000 & $\mathbf{0 . 0 2 9}$ \\
& Division D $v s$. Beach volleyball & $10 / 12$ & 45.000 & 0.323 \\
\hline Mesomorph component & Division B $v s$. Division C & $24 / 28$ & 175.500 & $\mathbf{0 . 0 0 3}$ \\
& Division B $v s$. Division D & $24 / 10$ & 105.500 & 0.580 \\
& Division B $v s$. Beach volleyball & $24 / 12$ & 143.500 & 0.986 \\
& Division C $v s$. Division D & $28 / 10$ & 83.000 & 0.058 \\
& Division C $v s$. Beach volleyball & $28 / 12$ & 85.500 & $\mathbf{0 . 0 1 4}$ \\
& Division D $v s$. Beach volleyball & $10 / 12$ & 53.000 & 0.640 \\
\hline
\end{tabular}

$\mathrm{n}$, number of players used in each of the comparisons; U, Mann-Whitney statistic; significance for $\mathrm{p} \leq 0.05$ indicated in bold. 
Table III. Descriptive statistics according to volleyball player functions.

\begin{tabular}{|c|c|c|c|c|c|}
\hline Player function (n) & Measure & Mean & \pm SD & Minimum & Maximum \\
\hline \multirow[t]{9}{*}{ Hitter (27) } & Height (cm) & 168.54 & 4.25 & 160.20 & 176.60 \\
\hline & Weight (kg) & 62.95 & 8.90 & 43.70 & 81.20 \\
\hline & Fat mass $(\%)$ & 23.69 & 2.67 & 19.90 & 29.00 \\
\hline & Body mass index $\left(\mathrm{kg} / \mathrm{m}^{2}\right)$ & 22.12 & 2.77 & 17.03 & 30.64 \\
\hline & Arm muscle area $\left(\mathrm{cm}^{2}\right)$ & 37.74 & 7.06 & 27.53 & 58.63 \\
\hline & Thigh muscle area $\left(\mathrm{cm}^{2}\right)$ & 158.89 & 27.15 & 111.43 & 228.96 \\
\hline & Endomorph component & 5.20 & 0.82 & 3.50 & 7.00 \\
\hline & Mesomorph component & 3.76 & 1.58 & 1.50 & 8.50 \\
\hline & Ectomorph component & 2.67 & 1.03 & 0.50 & 5.00 \\
\hline \multirow[t]{9}{*}{ Setter (10) } & Height $(\mathrm{cm})$ & 164.64 & 8.16 & 156.70 & 177.00 \\
\hline & Weight (kg) & 61.52 & 7.77 & 53.00 & 74.20 \\
\hline & Fat mass $(\%)$ & 26.38 & 2.99 & 21.60 & 31.80 \\
\hline & Body mass index $\left(\mathrm{kg} / \mathrm{m}^{2}\right)$ & 22.74 & 2.90 & 19.66 & 29.50 \\
\hline & Arm muscle area $\left(\mathrm{cm}^{2}\right)$ & 36.37 & 3.03 & 30.56 & 40.42 \\
\hline & Thigh muscle area $\left(\mathrm{cm}^{2}\right)$ & 152.46 & 23.64 & 129.83 & 200.98 \\
\hline & Endomorph component & 5.65 & 0.88 & 4.00 & 7.00 \\
\hline & Mesomorph component & 4.50 & 1.49 & 2.00 & 7.00 \\
\hline & Ectomorph component & 2.20 & 1.25 & 0.50 & 4.50 \\
\hline \multirow[t]{9}{*}{ Blocker (12) } & Height $(\mathrm{cm})$ & 172.38 & 4.18 & 165.00 & 178.60 \\
\hline & Weight (kg) & 63.93 & 6.98 & 48.90 & 72.70 \\
\hline & Fat mass $(\%)$ & 23.45 & 4.13 & 14.20 & 29.50 \\
\hline & Body mass index $\left(\mathrm{kg} / \mathrm{m}^{2}\right)$ & 21.49 & 2.01 & 17.96 & 23.94 \\
\hline & Arm muscle area $\left(\mathrm{cm}^{2}\right)$ & 35.88 & 4.63 & 30.00 & 45.11 \\
\hline & Thigh muscle area $\left(\mathrm{cm}^{2}\right)$ & 156.62 & 22.88 & 120.87 & 198.20 \\
\hline & Endomorph component & 5.33 & 1.09 & 3.00 & 6.50 \\
\hline & Mesomorph component & 3.04 & 1.34 & 0.50 & 5.50 \\
\hline & Ectomorph component & 3.08 & 1.02 & 1.50 & 5.00 \\
\hline \multirow[t]{9}{*}{ Libero (12) } & Height $(\mathrm{cm})$ & 160.48 & 4.80 & 154.00 & 167.80 \\
\hline & Weight (kg) & 61.06 & 7.65 & 50.90 & 77.20 \\
\hline & Fat mass $(\%)$ & 25.43 & 2.92 & 21.10 & 30.50 \\
\hline & Bodv mass index $\left(\mathrm{kg} / \mathrm{m}^{2}\right)$ & 23.70 & 2.75 & 20.21 & 29.78 \\
\hline & Arm muscle area $\left(\mathrm{cm}^{2}\right)$ & 39.43 & 7.52 & 30.04 & 54.63 \\
\hline & Thigh muscle area $\left(\mathrm{cm}^{2}\right)$ & 161.71 & 22.20 & 120.02 & 198.94 \\
\hline & Endomorph component & 5.71 & 0.78 & 4.00 & 6.50 \\
\hline & Mesomorph component & 5.46 & 2.13 & 3.00 & 10.00 \\
\hline & Ectomorph component & 1.58 & 0.90 & 0.50 & 3.00 \\
\hline \multirow[t]{9}{*}{ All-rounder (13) } & Height $(\mathrm{cm})$ & 166.11 & 8.13 & 148.50 & 183.70 \\
\hline & Weight (kg) & 61.23 & 5.52 & 50.10 & 67.30 \\
\hline & Fat mass $(\%)$ & 23.06 & 2.70 & 17.00 & 25.60 \\
\hline & Bodv mass index $\left(\mathrm{kg} / \mathrm{m}^{2}\right)$ & 22.20 & 1.52 & 19.08 & 24.13 \\
\hline & Arm muscle area $\left(\mathrm{cm}^{2}\right)$ & 35.20 & 4.53 & 29.82 & 45.03 \\
\hline & Thigh muscle area $\left(\mathrm{cm}^{2}\right)$ & 160.64 & 30.58 & 126.11 & 242.83 \\
\hline & Endomorph component & 4.89 & 0.71 & 3.50 & 6.00 \\
\hline & Mesomorph component & 3.35 & 1.09 & 1.00 & 5.00 \\
\hline & Ectomorph component & 2.39 & 1.00 & 1.00 & 5.00 \\
\hline
\end{tabular}

selective parameters for the players to gain access to the elite tournaments.

No statistically significant differences are observed among the Italian players in the different Divisions relative to body weight, FM\%, TMA, and the degree of endomorphism and ectomorphism. The Division B players are statistically taller than the Division C players, but have a comparable height to the players in Division D. This last similarity might be explained by the participation in Division D tournaments by players originally from higher Divisions and now towards the ends of their careers. Contrary to expectations, the Division $\mathrm{C}$ athletes showed significantly higher AMA and mesomorphic component than the Division B players.

The anthropometry and somatotype of Italian amateur volleyball players are comparable to those of the Italian beach volleyball players. Indeed, there were no significant differences between these two types of volleyball players, with the sole exceptions of AMA and the mesomorphic component, which were also limited to the comparisons with the Division C players.

\section{CONCLUSION}

The high stature and a good muscular development (demonstrated by the prevalence of the mesomorphic component

The higher presence of the endomorphic component distinguishes the Italian Division B, C and D players from those of Divisions A1 and A2, for whom mesomorphy dominates. In particular, the Italian Division B tournaments are played by athletes with different physical characteristics from those of the elite leagues (i.e., Divisions A1, A2): stature and good musculoskeletal system development appear to be over the others) characterizes the elite players and differentiates them from those of lower categories.

Regarding the amateur sector, the anthropometric profiles do not clearly distinguish the higher ranking volleyball players (i.e., Division $\mathrm{B}$ ) from the others (C and D Divisions). The jump in class between the lower Divisions 
Table IV. Results of Mann-Whitney analysis (U) for evaluation of the significance (p) of the mean differences between the various player functions.

\begin{tabular}{|c|c|c|c|c|}
\hline Measure & Player function comparison & $n$ & $\boldsymbol{U}$ & $p$ \\
\hline \multirow[t]{10}{*}{ Height $(\mathrm{cm})$} & Hitter $v s$. Setter & $27 / 10$ & 86.000 & 0.094 \\
\hline & Hitter vs. Blocker & $27 / 12$ & 83.500 & $\mathbf{0 . 0 1 7}$ \\
\hline & Hitter $v s$. Libero & $27 / 12$ & 34.000 & 0.000 \\
\hline & Hitter $v s$. All-rounder & $27 / 13$ & 134.500 & 0.236 \\
\hline & S etter $v s$. Blocker & $10 / 12$ & 29.000 & 0.041 \\
\hline & S etter vs. Libero & $10 / 12$ & 45.500 & 0.339 \\
\hline & S etter $v s$. All-rounder & $10 / 13$ & 52.000 & 0.420 \\
\hline & Blocker vs. Libero & $12 / 12$ & 4.500 & 0.000 \\
\hline & Blocker vs. All-rounder & $12 / 13$ & 28.000 & 0.006 \\
\hline & Libero vs. All-rounder & $12 / 13$ & 36.000 & 0.022 \\
\hline \multirow[t]{10}{*}{ Fat mass (\%) } & Hitter $v s$. Setter & $27 / 10$ & 67.000 & $\mathbf{0 . 0 2 0}$ \\
\hline & Hitter vs. Blocker & $27 / 12$ & 157.500 & 0.891 \\
\hline & Hitter $v s$. Libero & $27 / 12$ & 111.000 & 0.121 \\
\hline & Hitter $v s$. All-rounder & $27 / 13$ & 160.500 & 0.665 \\
\hline & S etter vs. Blocker & $10 / 12$ & 34.500 & 0.093 \\
\hline & Setter $v s$. Libero & $10 / 12$ & 43.000 & 0.262 \\
\hline & S etter $v s$. All-rounder & $10 / 13$ & 19.500 & 0.005 \\
\hline & Blocker vs. Libero & $12 / 12$ & 49.000 & 0.184 \\
\hline & Blocker vs. All-rounder & $12 / 13$ & 70.500 & 0.683 \\
\hline & Libero vs. All-rounder & $12 / 13$ & 45.500 & 0.077 \\
\hline \multirow[t]{10}{*}{ Mesomorph component } & Hitter $v s$. Setter & $27 / 10$ & 91.500 & 0.134 \\
\hline & Hitter vs. Blocker & $27 / 12$ & 122.500 & 0.226 \\
\hline & Hitter $v s$. Libero & $27 / 12$ & 74.500 & 0.007 \\
\hline & Hitter $v s$. All-rounder & $27 / 13$ & 159.500 & 0.640 \\
\hline & S etter $v s$. Blocker & $10 / 12$ & 28.000 & $\mathbf{0 . 0 3 3}$ \\
\hline & S etter $v s$. Libero & $10 / 12$ & 48.000 & 0.425 \\
\hline & S etter $v s$. All-rounder & $10 / 13$ & 34.500 & 0.056 \\
\hline & Blocker vs. Libero & $12 / 12$ & 22.000 & 0.004 \\
\hline & Blocker vs. All-rounder & $12 / 13$ & 65.000 & 0.473 \\
\hline & Libero $v s$. All-rounder & $12 / 13$ & 27.500 & 0.005 \\
\hline \multirow[t]{10}{*}{ Ectomorph component } & Hitter $v s$. Setter & $27 / 10$ & 103.500 & 0.276 \\
\hline & Hitter vs. Blocker & $27 / 12$ & 134.500 & 0.395 \\
\hline & Hitter $v s$. Libero & $27 / 12$ & 68.500 & 0.004 \\
\hline & Hitter $v s$. All-rounder & $27 / 13$ & 131.000 & 0.191 \\
\hline & S etter $v s$. Blocker & $10 / 12$ & 33.000 & 0.073 \\
\hline & S etter $v s$. Libero & $10 / 12$ & 42.000 & 0.229 \\
\hline & S etter $v s$. All-rounder & $10 / 13$ & 55.000 & 0.530 \\
\hline & Blocker vs. Libero & $12 / 12$ & 20.000 & 0.002 \\
\hline & Blocker vs. All-rounder & $12 / 13$ & 45.000 & 0.066 \\
\hline & Libero vs. All-rounder & $12 / 13$ & 43.000 & 0.053 \\
\hline
\end{tabular}

$\mathrm{n}$, number of players used in each of the comparisons; $\mathrm{U}$, Mann-Whitney statistic; significance for $\mathrm{p} \leq 0.05$ indicated in bold. developed ectomorphic component, while the mesomorphic component prevails in the setters and liberos.

D'ANASTASIO, R.; MILIVOJEVIC, A.; CILLI, J.; ICARO, I. \& VICIANO, J. Perfiles antropométricos y somatotipos de jugadoras de voleibol femenino y voleibol de playa. Int. J. Morphol., 37(4):1480-1485, 2019.

RESUMEN: El objetivo de este estudio fue comparar los perfiles antropométricos, la composición corporal y los somatotipos de jugadoras de voleibol agrupadas según el estado de jugador (División de la Liga Nacional) y la función. El estudio evaluó 62 jugadoras de voleibol y 12 jugadoras de voleibol de playa (edad media, 23,58, $\mathrm{s}=$ 7,74 años). Las medidas antropométricas incluyeron altura, masa corporal, circunferencias y diámetros corporales, y grosor del pliegue cutáneo adiposo. Los datos se analizaron mediante un software proporcionando el índice de masa corporal, el porcentaje de masa grasa, el área muscular del brazo, el área muscular del muslo y el somatotipo. El análisis estadístico se realizó con el software SPSS Statistics versión 22. Las jugadoras de voleibol de la División B eran más altas que las de la División C $(169,19, \mathrm{~s}=6,68 \mathrm{~cm}$ vs. $165,40, \mathrm{~s}=$ $6,19 \mathrm{~cm} ; \mathrm{P}<0,05)$, pero mostraron una zona muscular del brazo inferior $\left(34,77, \mathrm{~s}=3,57 \mathrm{~cm}^{2}\right.$ vs. $\left.40,06, \mathrm{~s}=7,27 \mathrm{~cm}^{2} ; \mathrm{p}<0,05\right)$ y mesomorfia $(3,40$, $\mathrm{s}=1,21$ vs. $4,84, \mathrm{~s}=2,10 ; \mathrm{P}<0,05)$. Para las funciones del jugador, las bloqueadoras fueron las más altas $(172,38, \mathrm{~s}=4,18 \mathrm{~cm} ; \mathrm{p}<0,05)$ y mostraron la ectomorfia más alta $(3,08, \mathrm{~s}=1,02 ; \mathrm{p}<0,05)$, las colocadoras mostraron el mayor porcentaje de masa grasa $(26,38 \%, \mathrm{~s}=2,99 \%$ : $\mathrm{p}<0,05)$, y los "liberos" mostraron una mesomorfia más compacta $(5,46, \mathrm{~s}=2,13)$ y ectomorfia baja $(1,58, \mathrm{~s}=0,90)$. Los datos antropométricos mostraron pocas diferencias significativas entre las divisiones de voleibol, lo que sugiere que la promoción de las divisiones se debe a la capacidad técnica más que a las cualidades físicas. Los perfiles antropométricos de las jugadoras variaron según sus funciones dentro de su equipo de voleibol.

PALABRAS CLAVE: Composición corporal; Equipo de deporte; Medición. (i.e., Divisions C, D) and Division B is dictated not so much by the physical qualities of the players, but rather by their technical skills.

In Italian amateur tournaments (i.e., Divisions B, C, D), the different functions of the players show anthropometric data distributions that tend to reflect those of the elite athletes; i.e., the blockers and hitters are taller and have a more

\section{REFERENCES}

Brozek, J.; Grande, F.; Anderson, J. T. \& Keys, A. Densitometric analysis of body composition: revision of some quantitative assumptions. Ann. N. Y. Acad. Sci., 110:113-40, 1963.

Cagnazzo, F. \& Cagnazzo, R. Valutazione Antropometrica in Clinica, Riabilitazione e Sport. Milano, Ermes, 2009.

Carvajal, W.; Betancourt, H.; León, S.; Deturnel, Y.; Martínez, M.; Echevarría, I.; Castillo, M. E. \& Serviat, N. Kinanthropometric profile of Cuban women 
Table V. Analysis of the reproducibility of the measures $(n=74$, for all) through the intraclass correlation coefficients, which demonstrate the strength of agreement according to Fleiss of 'very good' for all measures.

\begin{tabular}{|c|c|c|c|c|c|c|c|c|}
\hline \multirow[t]{2}{*}{ Specific } & \multirow[t]{2}{*}{ Measure } & \multicolumn{2}{|c|}{ Observation 1} & \multicolumn{2}{|c|}{ Observation 2} & \multicolumn{2}{|c|}{ Observation 3} & \multirow{2}{*}{$\begin{array}{c}\text { Correlation } \\
\text { coefficient }\end{array}$} \\
\hline & & Mean & \pm SD & Mean & \pm SD & Mean & \pm SD & \\
\hline \multirow[t]{2}{*}{ Player } & Height $(\mathrm{cm})$ & 166.904 & 6.720 & 166.904 & 6.720 & 166.904 & 0.720 & 1.000 \\
\hline & W eight (kg) & 62.307 & 7.613 & 62.307 & 7.613 & 62.307 & 7.613 & 1.000 \\
\hline \multirow{10}{*}{$\begin{array}{l}\text { Circumference } \\
(\mathrm{cm})\end{array}$} & Right arm & 26.039 & 2.161 & 25.982 & 2.234 & 25.923 & 2.209 & 0.996 \\
\hline & Left arm & 26.004 & 2.195 & 26.023 & 2.187 & 25.949 & 2.157 & 0.998 \\
\hline & Forearm $(\mathrm{cm})$ & 23.508 & 1.283 & 23.476 & 1.344 & 23.438 & 1.347 & 0.996 \\
\hline & W rist & 15.814 & 0.654 & 15.828 & 0.646 & 15.819 & 0.642 & 0.985 \\
\hline & Waist & 69.176 & 4.943 & 69.220 & 5.058 & 69.134 & 4.963 & 0.998 \\
\hline & Hips & 91.369 & 6.021 & 91.155 & 5.863 & 91.089 & 5.847 & 0.996 \\
\hline & Thigh & 55.141 & 4.154 & 55.146 & 4.193 & 55.108 & 4.204 & 0.999 \\
\hline & Mid-thigh & 50.707 & 3.555 & 50.474 & 3.491 & 50.503 & 3.565 & 0.995 \\
\hline & Above right knee & 38.386 & 2.789 & 38.297 & 2.895 & 38.180 & 2.803 & 0.989 \\
\hline & Calf & 35.482 & 2.123 & 35.493 & 2.169 & 35.482 & 2.120 & 0.996 \\
\hline \multirow[t]{4}{*}{ Diameter $(\mathrm{cm})$} & Elbow & 6.291 & 0.677 & 6.214 & 0.649 & 6.174 & 0.635 & 0.992 \\
\hline & Wrist & 4.853 & 0.306 & 4.839 & 0.296 & 4.828 & 0.280 & 0.987 \\
\hline & Knee & 9.973 & 0.741 & 9.951 & 0.719 & 9.924 & 0.724 & 0.994 \\
\hline & Ankle & 6.293 & 0.375 & 6.276 & 0.372 & 6.288 & 0.365 & 0.989 \\
\hline \multirow{12}{*}{$\begin{array}{l}\text { Skinfold thickness } \\
(\mathrm{mm})\end{array}$} & Tricipital & 20.130 & 4.264 & 20.419 & 4.133 & 20.439 & 4.171 & 0.988 \\
\hline & Bicipital & 8.200 & 2.366 & 8.030 & 2.238 & 7.976 & 2.257 & 0.986 \\
\hline & Pectoral & 10.189 & 3.306 & 10.092 & 3.494 & 10.057 & 3.565 & 0.995 \\
\hline & Sub-scapular & 13.659 & 4.169 & 13.653 & 4.189 & 13.496 & 4.117 & 0.996 \\
\hline & Abdominal & 20.762 & 4.412 & 20.830 & 4.383 & 20.545 & 4.473 & 0.994 \\
\hline & Supra-iliac & 19.888 & 4.213 & 19.850 & 4.186 & 19.664 & 4.271 & 0.989 \\
\hline & Front of the thigh & 21.624 & 3.742 & 21.622 & 3.971 & 21.564 & 3.926 & 0.989 \\
\hline & Back of the thigh & 18.084 & 3.478 & 18.205 & 3.344 & 18.047 & 3.477 & 0.986 \\
\hline & Inside of the thigh & 19.238 & 4.700 & 19.384 & 4.490 & 19.372 & 4.482 & 0.992 \\
\hline & Above right knee & 17.627 & 3.212 & 17.400 & 3.382 & 17.241 & 3.273 & 0.987 \\
\hline & Above left knee & 17.465 & 3.738 & 17.235 & 3.775 & 17.065 & 3.784 & 0.985 \\
\hline & Popliteal $^{\mathrm{a}}$ & 18.457 & 4.167 & 18.146 & 4.491 & 18.000 & 4.390 & 0.988 \\
\hline
\end{tabular}

abehind the knee.

Olympic volleyball champions. MEDICC Rev., 14(2):16-22, 2012.

Duncan, M. J.; Woodfield, L. \& al-Nakeeb, Y. Anthropometric and physiological characteristics of junior elite volleyball players. Brit. J. Sports Med., 40(7):649-51, 2006.

Fleiss, J. L. The Design and Analysis of Clinical Experiments. New York, Wiley Classics Library, 1986.

Gabbett, T. \& Georgieff, B. Physiological and anthropometric characteristics of Australian junior national, state, and novice volleyball players. J. Strength Cond. Res., 21(3):902-8, 2007.

González-Ravé, J. M.; Arija, A. \& Clemente-Suarez, V. Seasonal changes in jump performance and body composition in women volleyball players. $J$. Strength Cond. Res., 25(6):1492-501, 2011.

Gualdi-Russo, E. \& Zaccagni, L. Somatotype, role and performance in elite volleyball players. J. Sports Med. Phys. Fitness, 41(2):256-62, 2001.

Heat, B. H. \& Carter, J. E. A modified somatotype method. Am. J. Phys. Anthropol., 27(1):57-74, 1967.

Jackson, A. S.; Pollock, M. L. \& Ward, A. Generalized equations for predicting body density of women. Med. Sci. Sports Exerc., 12(3):175-81, 1980.

Lidor, R. \& Ziv, G. Physical and physiological attributes of female volleyball players--a review. J. Strength Cond. Res., 24(7):1963-73, 2010.

Marques, M. C.; van den Tillaar, R.; Gabbett, T. J.; Reis, V. M. \& GonzálezBadillo, J. J. Physical fitness qualities of professional volleyball players: determination of positional differences. J. Strength Cond. Res., 23(4):110611, 2009.

Nikolaidis, P. T. Body mass index and body fat percentage are associated with decreased physical fitness in adolescent and adult female volleyball players. J. Res. Med. Sci., 18(1):22-6, 2013.
Nikolaidis, P. T.; Ziv, G.; Arnon, M. \& Lidor, R. Physical characteristics and physiological attributes of female volleyball players--the need for individual data. J. Strength Cond. Res., 26(9):2547-57, 2012

Sheppard, J. M.; Chapman, D. W.; Gough, C.; McGuigan, M. R. \& Newton, R. $\mathrm{U}$. Twelve-month training-induced changes in elite international volleyball players. J. Strength Cond. Res., 23(7):2096-101, 2009a.

Sheppard, J. M.; Gabbett, T. J. \& Stanganelli, L. C. An analysis of playing positions in elite men's volleyball: considerations for competition demands and physiologic characteristics. J. Strength Cond. Res., 23(6):1858-66, 2009 b.

Trajkovic, N.; Milanovic, Z.; Sporis, G. \& Radisavljevic, M. Positional differences in body composition and jumping performance among youth elite volleyball players. Acta Kinesiol., 5(1):62-6, 2011.

Corresponding author:

Ruggero D'Anastasio, PhD

Assistant Professor of Anthropology

Department of Medicine and Aging Sciences

State University "G. d'Annunzio"

Chieti-Pescara, Italy, c/o

Museo Universitario Piazza Trento e Trieste

ITALY

Email: r.danastasio@unich.it

Received: 18-03-2019

Accepted: 03-06-2019 